上顎洞に広範に進展した腺様歯原性腫瘍の 1 例

\author{
川村信五・関口＼cjkstart隆・原田雅史 \\ 永井 格*・賀来 亨**
}

\title{
A case of adenomatoid odontogenic tumor extending widely in the maxillary sinus
}

\author{
KAWAMURA Shingo $\cdot$ SEKIGUCHI Takashi $\cdot$ HARADA Masashi \\ NAGAI Itaru* $\cdot$ KAKU Tohru**
}

\begin{abstract}
Adenomatoid odontogenic tumor (AOT) is an uncommon odontogenic lesion characterized histologically by ductal structures of epithelial cells and foci of calcification. Typically, these lesions arise in the lateral incisor / canine region in alveolar bone of the maxilla. Rarely, the lesion exhibits aggressive behavior, such as becoming large or extending into the paranasal sinuses. This article describes a case of AOT that extended widely in the maxillary sinus.

A 18-year-old woman was referred to our clinic for evaluation of a mixed radiolucent-radiopaque lesion with a well defined border in the right maxillary sinus. A computerized tomographic evaluation demonstrated a defined large lesion that had extended widely in the right maxillary sinus, with thinning the cortical bone of the maxilla. The lesion was associated with an unerupted tooth on the corresponding region of the nasal cavity.

An incisional biopsy was performed under local anesthesia. The pathological diagnosis was AOT. Surgery was performed with the patient under general anesthesia. The tumor was enucleated completely via an intraoral approach. There has been no recurrence as of 5 months after surgery.
\end{abstract}

Key words: adenomatoid odontogenic tumor (腺様歯原性腫瘍), maxillary sinus (上顎洞), unerupted tooth (埋伏歯)

\section{緒言}

腺様歯原性腫瘍 (adenomatoid odontogenic tumor, 以 下 AOT と略) はWHO 国際分類において, 歯原性の外胚 葉性間葉組織を伴う歯原性上皮から発生する良性腫瘍の範 疇に位置づけられている ${ }^{1)}$. 本腫瘍は発生頻度の少ない歯

医療法人溪仁会手稲溪仁会病院歯科口腔外科

(主任 : 関口 隆部長)

*札幌医科大学医学部口腔外科学講座

(主任 : 小浜源郁教授)

**北海道医療大学歯学部口腔病理学講座

(主任 : 賀来 亨教授)

Department of Dentistry and Oral Surgery, Teine Keijinkai Hospital (Chief: Dr. SEKIGUCHI Takashi)

${ }^{*}$ Department of Oral Surgery, Sapporo Medical University School of Medicine (Chief: Prof. KOHAMA Gen-iku)

** Department of Oral Pathology, Health Sciences University of Hokkaido School of Dentistry (Chief: Prof. KAKU Tohru)

受付日：2003年 1 月 7 日

採択日：2003年 4 月 22 日
原性腫瘍のなかでもさらにまれな腫瘍で，その多くは上顎 前歯部に発生するが，上顎洞へ進展するものはまれであ

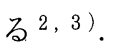

今回われわれは上顎洞に広範に進展した AOT の 1 例を 経験したので, その概要を報告する.

症例

患 者 : 18歳, 女性

初 診: 平成14年 4 月

主 訴: 右上顎洞の精査.

既往歴, 家族歴 : 特記事項なし.

現病歴 : 平成 14 年 4 月凹, 歯科治療のため某歯科医院 を受診し, パノラマX 線写真において右上顎洞内に散在性 の石灰化様不透過像を有する透過性病変を認めたため, 専 門医療機関の受診を勧められ当科を受診した.

現 症:

全身所見 ; 全身的には体格は中等度で栄養状態は良好で 


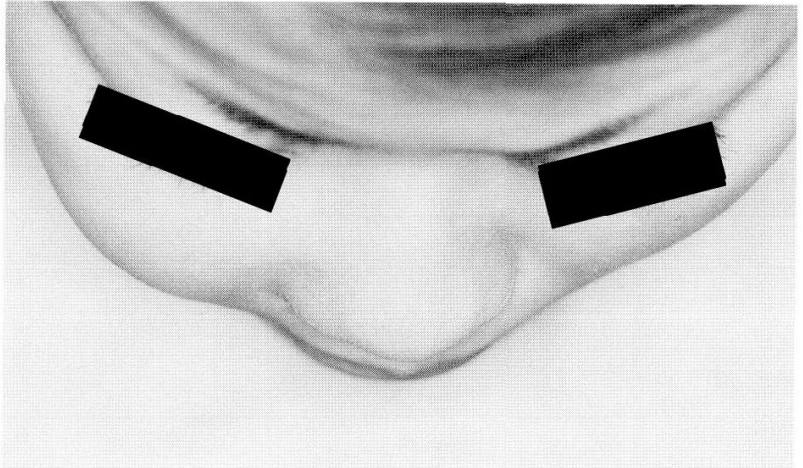

写真 1 初診時顔貌写真

右煩部に比較的境界明瞭な無痛性・肖様硬の腫脹を認 める.

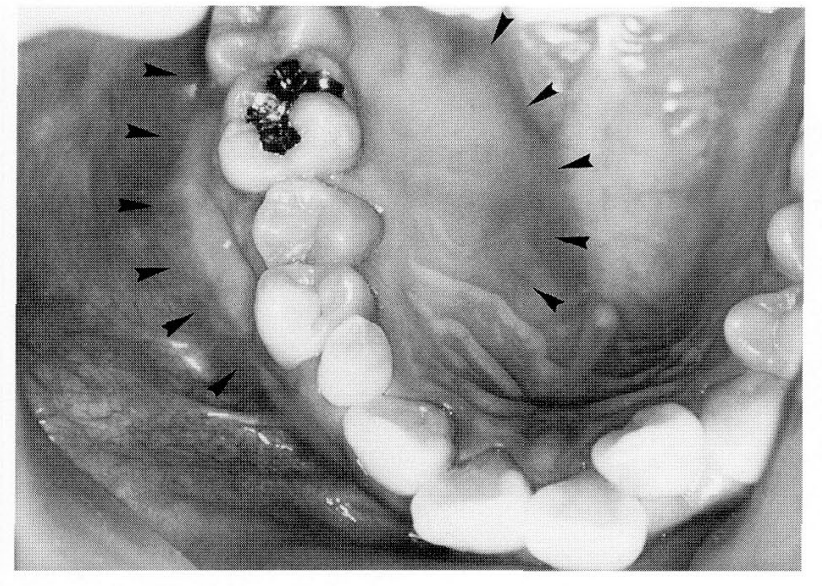

写真 2 初診時口腔内写真 (ミラー像)

$7654 \mathrm{C}$ の煩側・口蓋側に比較的境界明暸な骨様 硬の膨隆（矢頭）を認める。

あった。

口腔外所見; 顔貌は左右非刘称で右煩部に比較的境界明 瞭な無痛性, 骨様硬の腫脹を認めた (写真 1 ). 右鼻腔は膨 隆により狭窄しており，鼻閉を認めた。

口腔内所見；7654 C の煩側 - 口盖側に比較的境 界明瞭な骨様硬の澎隆を認め, 口蓋側は羊皮紙様感を呈し, $7654 \mathrm{C}$ は動摇を認めた (写真 2 ).

画像診断所見：パノラマX 線写真では右上顎洞に砂粒 状の石灰化像とその鼻腔側に埋伏歯を伴う境界明瞭な単房 性透過像を認め, $7654 \mathrm{C} \mid$ の歯根尖は吸収していた (写真 3 ). X 線 CT 写真では, 右上顎洞を広範に占有し鼻 腔および篩骨洞の一部に及ぶ類円形の腫瘤を認め，内部に は大小不同の砂粒状の石灰化様不透過像と埋伏歯が認めら れた (写真 4 ). また, 右眼窩底, 鼻腔側壁, 上顎洞前壁・後 外側壁，口蓋側壁は菲薄化，膨隆していた。

臨床診断：上顎歯原性腫瘍.

処置および経過 : 平成14年 4 外来局所麻酔下に

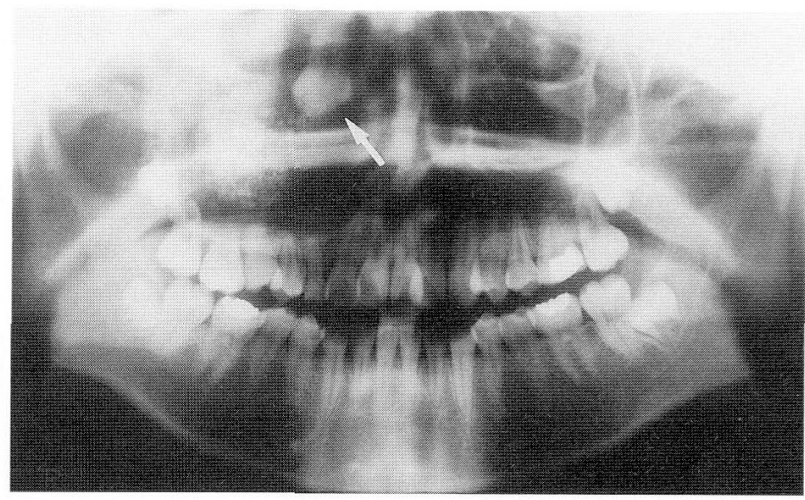

写真 3 パノラマ X 線写真

右上顎洞に砂粒状の石灰化像と埋伏歯（矢印）を伴う 境界明瞭な透過像が認められる.7654 C| の菌根尖 は吸収している。

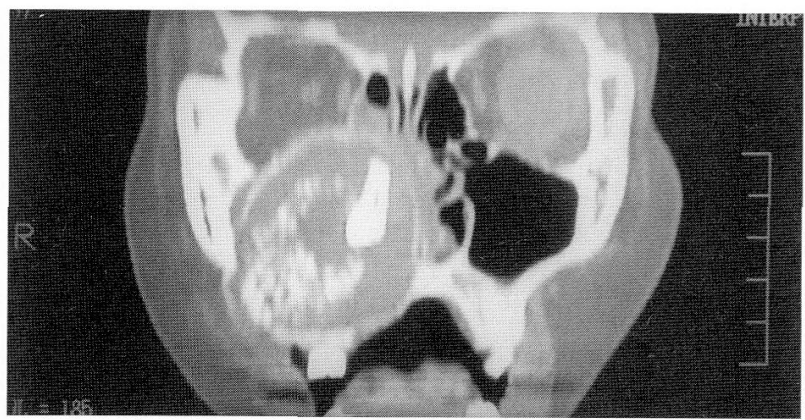

写真 4 前額断 X 線 CT 写真

右上䫈洞を広範に占有し鼻腔および篩骨洞の一部に及 ぶ類円形の腫瘤を認める。

腫瘤内部には大小不同の砂粒状の石灰化様不透過像と 埋伏歯が認められる。

口腔内より生検を施行した.上顎骨前壁は菲薄化, 膨隆し ており，同部の骨を一部除去することにより被膜を有した 腫瘤が容易に露出した. 生検組織の病理組織学的所見では, 腫瘍は比較的疎な線維性結合組織で被包されており実質組 織に富み, 紡錘形, 多角形の腫瘍細胞が渦巻き状, 索状に増 殖し, 円柱状, 立方状の腫瘍細胞は小腺管様構造を形成し ていた. 以上の所見より, 病理組織学的にAOT と診断した (写真 5 ).

平成14年 7 月, $\mathrm{AOS}$ 全身麻酔下に口内法により腫瘍 摘出術を施行した. $7654 \mathrm{C}$ の抜歯を行い, 同部の煩 側・蓋側の粘膜骨膜弁を剥離・翻転し, 菲薄化した骨を 除去し腫瘍表面を露出させた. 腫瘍の表面は平滑で線維性 被膜を有し, 周囲組織からの剥離は, 生検部の癒着もなく 比較的容易であった。なお, 眼窩直下, 篩骨洞, 鼻腔側部で は腫瘍を慎重に剥離した. 腫瘍摘出後には口蓋骨, 上顎歯 槽骨，上顎骨前壁に広範な欠損が生じたため，チタン・ メッシュにて再建を行った。 


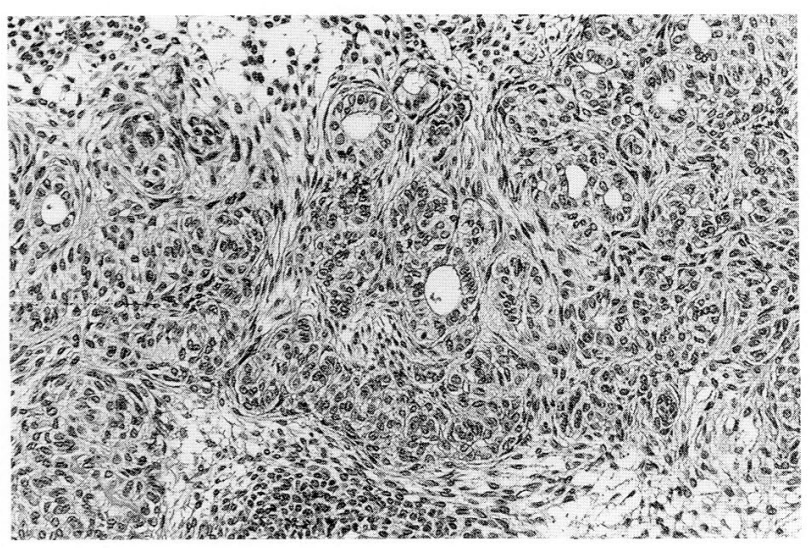

写真 5 生検組織の病理組織像 $(\mathrm{H}-\mathrm{E}$ 染色, $\times 170)$ 紡鍾形, 多角形の腫瘍細胞が渦巻き状，索状に増殖し ている.

円柱状，立方状の腫瘍細胞は腺管様構造を形成してい る。

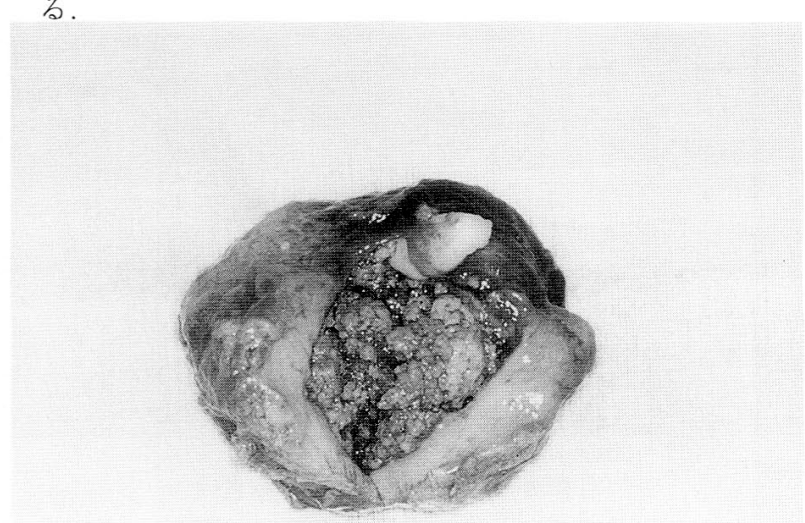

$\begin{array}{llllllllll}10 & 20 & 30 & 40 & 50 & 60 & 70 & 80 & 90 & 100\end{array}$

写真 6 摘出標本の割面写真

割面は充実性で内部には砂粒状の石灰化様物質が含ま れている。

術後 5 か月を経過した現在, 右上顎涧に腫瘍の再発兆候 や異常所見はなく, 経過は良好である.

摘出標本所見 : 摘出標本の大きさは $4.0 \times 4.0 \times 3.5 \mathrm{~cm}$ で 3 と考えられる歯牙を含み, 表面は带黄色, 平滑で弾性 硬であり, 割面は充実性で内部には砂粒状の石灰化様物質 が含まれていた（写真 6 ).

病理組織学的所見：腫瘍の周囲は厚い線維性結合組織で 被包されており, 紡錘形, 多角形の上皮細胞が渦巻き状, シート状に充実性に増殖し, 円柱状細胞が腺管様構造を形 成していた。また,一部の腫瘍胞巣には小石死化巣が散在 性に認められ (写真 7 ), 小柱構造が観察される未成熟な工 ナメル質様基質とエオジン好性の異形成象牙質様の硬組織 も認められた (写真 8 ).

病理組織学的診断 : 腺様歯原性腫瘍.

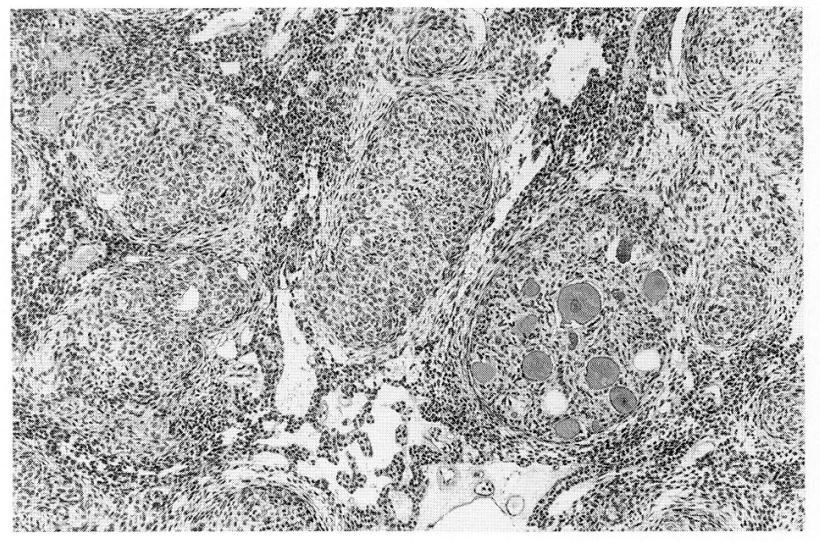

写真 7 摘出標本組織の病理組織像 $(\mathrm{H}-\mathrm{E}$ 染色, $\times 85)$ 腫場胞巣内に小石灰化巣が散在性に認められる.

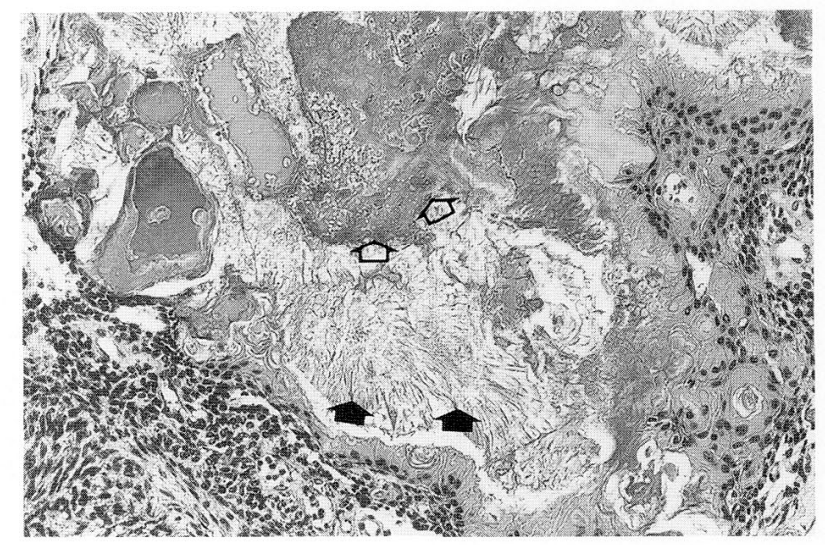

写真 8 摘出標本組織の病理組織 $(\mathrm{H}-\mathrm{E}$ 染色, $\times 170)$ 小柱構造が観察される未成熟なエナメル質様基質 （1）と異形成象牙質様の硬組織（令）が認められる.

\section{考察}

AOT は外胚葉性菌原性腫瘍で，以前はエナメル上皮腫 の曲型として腺様エナメル上皮腫と命名されていた ${ }^{4)}$. し かし, 近年では臨床的, 組織学的, 生物学的にエナメル上皮 腫とは明らかに区別され，一般的には過誤腫とみなされて いる 1,5 )

Philipsen ら 2)によるAOT 499例の検討では，好発年齢 は10歳台後半で, 性別では女性に多く, 上顎前歯部に好発 するとされている.また本腫瘍の大多数は顎骨中心性に緩 慢に発育増大し, 皮質骨を圧迫性に膨隆させ $\left.{ }^{2}, 6\right)$ ，一般的 には $1 \sim 3 \mathrm{~cm}$ の腫瘍塊に成長する7).しかしときに新生 物のように活発に発育増大し, 大きな腫瘍塊に成長し皮質 骨の穿孔をきたしたり 8 ), 副鼻腔 ${ }^{3}$ ), 頭蓋底 ${ }^{9}$ ) へ進展する まれな症例も報告されている. 自験例では腫瘍の発育増大 による皮質骨の穿孔はみられなかったが, 腫瘍は右上顎洞 を広範に占有し鼻腔および篩骨洞の一部にまで進展してい 
た.このことは腫瘍が新生物のような活発な生物学的態 度 $3,8,9)$ を有していたことを示唆する所見と考えられ, 発 生部位, 進展範囲からみて自験例はまれな症例と考えられ た。

X 線学的に本腫瘍は, 単房性透過像を示し, 内部にはし ばしば上顎前歯, とくに犬歯が埋伏し, 散在性・砂粒状の 石灰化様不透過像が認められることが多い2,7). また, 腫 瘍に隣接する歯根の離開をきたすが, 歯根吸収はまれであ るとされている7). 自験例では右上顎洞に砂粒状の石灰化 様不透過像と埋伏歯を含む境界明瞭な透過像を認めた。さ らに, 興味深い所見は病変に近接する7654 C は著明 に動摇し明らかな歯根吸収が認められたことである。この ことは, 自験例では腫瘍が顎骨内で長期間にわたり緩慢に 広範に発育増大したことを示唆する所見であると考えられ た。

病理組織学的に本腫瘍は, 線維性組織で被包され, 腫瘍 実質に富み, 腫瘍細胞は円柱状, 多角形, 紡錘形などを呈 し, 立方状ないし円柱状細胞で囲まれた腺管様構造が散在 性に認められる.また腫瘍組織内には小石灰化物が散在性 に認められるとされている1,10). 自験例では生検組織, 手 術摘出標本組織ともに腫瘍実質に腺管様構造の形成ならび に石灰化物の沈着を認め, 上述の病理組織学的所見と一致 するものであった。

本腫瘍の発生起源については現在まで明確な概念はない が, Philipsen $5^{2)}$ はエナメル器, 歯堤上皮, 退縮エナメル 上皮あるいはこれらの残遺物から発生したものではないか という考えを述べている. 一方 Robert ら ${ }^{11)}$ は, 電顕的に 本腫瘍の細胞をエナメル器を構成する上皮細胞の形態と比 較し, 内エナメル上皮細胞に類似するI 型と, 中間層ない し星状網に類似する II 型に分類し, 本腫瘍が歯胚形成期の エナメル器の上皮細胞に由来する可能性を指摘している. 自験例では腫瘍組織内の一部に未熟なエナメル質様基質と 異形成象牙質様の硬組織が認められた. このことは腫瘍の 発生起源にエナメル器の上皮細胞が密接に関与し, さらに これらの上皮細胞と間葉性細胞との相互作用 ${ }^{12)} に よ り$ 歯 牙様構造物が形成された可能性を示唆する所見と考えら れた. また, 本腫瘍が埋伏する上顎犬歯に関連して好発す $ろ^{2}$ ) 理由は不明であるが, 自験例においても腫瘍内に 3 が埋伏していた。このことから自験例では, 鼻腔側に位置 異常をきたした 3 の歯胚が, 歯胚の発育形成期にエナ メル器の一部の上皮細胞が腫瘍発生に関与し, 上顎洞内に 腫瘍を形成したものと推察された。

治療法に関しては, 本腫瘍は厚い被膜を有し病変の進展 範囲が明瞭なため, 摘出は比較的容易で再発はまれとされ
ている13). 自験例においても腫瘍は線維性被膜を有し, 周 囲組織からの剥離摘出は容易であった。摘出後は口蓋骨, 上顎歯槽骨, 上顎骨前壁に広範な欠損が生じたためチ夕 ン・メッシュにて再建し, 術後の煩部陥凹の予防と今後予 定される骨移植の際のスペース・メーキングを行った. 術 後 5 か月を経過しているが腫瘍の再発兆候はなく経過は良 好であり, 今後は骨移植を行いインプラント補綴にて咬合 の回復を図る予定である。

\section{引用文 献}

1) Kramer, I.R.H., Pindborg, J.J., et al.: Histological typing of odontogenic tumors. 2 nd Ed, Springer-Verlag, Berlin, 1992, p19-20.

2) Philipsen, H.P., Reichart, P.A., et al.: Adenomatoid odontogenic tumor: biologic profile based on 499 cases. J Oral Pathol Med 20: 1491581991.

3) Takahashi, K., Yoshino, T., et al.: Unusually large cystic adenomatoid odontogenic tumor of the maxilla: case report. Int J Oral maxillofac Surg 30: 173-175 2001.

4) Abrams, A.M., Melrose, R.J., et al.: Adenoameloblastoma. A clinical pathologic study of ten new cases. Cancer 22: 175-185 1968.

5) Regezi, J.A. and Sciubba, J.J.: Oral pathology - clinical pathologic correlation - . $3 \mathrm{rd}$ ed, W.B. Saunders, Philadelphia, 1999, p339.

6) Philipsen, H.P., Reichart, P.A., et al.: Adenomatoid odontogenic tumor: facts and figures. Oral Oncol 35: 125-131 1998.

7) Dare, A., Yamaguchi, A., et al.: Limitation of panoramic radiography in diagnosing adenomatoid odontogenic tumor. Oral Surg Oral Med Oral Pathol 77: 662-668 1994.

8) Raubenheimer, E.J., Seeliger, J.E., et al.: Adenomatoid odontogenic tumor; report of two large lesions. Dentomaxillofac Radiol 20: 43-45 1991.

9）滝上真良, 上出延治, 他 : 頭蓋内へ進展した腺様歯 原性腫瘍の 1 例. 脳神経外科 16: 775-779 1988.

10）石川梧朗監修：口腔病理学 II. 改訂版, 永末書店, 京都, 1982, 481-486頁.

11) Robert, R.L., Smith, M.D., et al.: Adenomatoid odontogenic tumor. Ultrastructual demonstration of two cell types and amyloid. Cancer 43: 505-511 1979.

12) Mjor, I.A. and Fejerskov, O. 編 : Histology of the Human Tooth. 改訂 人の歯の組織学, 第 2 版, 書林, 東京, 1980, 37頁.

13) Engin, B., Ferda, T., et al.: An adenomatoid odontogenic tumor with unusual clinical features. J Oral Sci 43: 283-286 2001. 